\title{
Assessment of water quality of River Ganga at Haridwar with reference to Water Quality Index
}

\author{
Ruhela Mukesh ${ }^{1}$, Kumar Paritosh ${ }^{1}$, Tyagi Varun $\varpi^{2}$, Ahamad Faheem ${ }^{2}$ and Ram Khushi ${ }^{2}$
}

Received: 20.06.2018

Revised: 25.08.2018

Accepted: 18.09.2018

\begin{abstract}
The holy River Ganga at Haridwar is largely affected by that effluent from varius industries and untreated sewage disposed from insufficient sewage treatment plants. Along with that the pilgrims that take holy dip in the pious river throughout the year, all these sitautions worsens the condition a lot. The quality and quantity of surface water in a river basin is influenced by natural factors such as rainfall, temperature and weathering of rocks and anthropogenic changes that curtail natural flow of the river, or alter its hydrochemistry. A study related to water quality indexing of River Ganga was conducted for four months, and four sampling stations were selected for physico-chemical parameters. WQI of the River during the study period was 46.03 which fall in the good water quality. DO values ranged from 10.32 - 13.24 $\mathrm{mg} / \mathrm{l}, \mathrm{BOD}$ values were $1.08-3.66 \mathrm{mg} / \mathrm{L}$, COD ranged from $5.50-11.50 \mathrm{mg} / \mathrm{L}$. Other physico-chemical parameters were observed well in the range.
\end{abstract}

Keywords: River Ganga, Dissolved Oxygen, Water Quality Index, Physico-chemical parameters

\section{Introduction}

Water plays an essential role in human life. Although statistics, the WHO reports that approximately $36 \%$ of urban and $65 \%$ of rural Indian were without access to safe drinking water. Fresh water is one of the most important resources crucial for the survival of all the living beings. It is even more important for the human being as they depend upon it for food production, industrial and waste disposal, as well as cultural requirement. In total, there is 1400 million billion liters of water, but most of this water is not used for drinking purpose, because $97 \%$ is sea water and only $3 \%$ is fresh water, out of which $2 \%$ is lidged in the polar ice caps and glaciers, only $1 \%$ water is available for portable use; whereas more water goes for irrigation than to drinking sanitation and all other uses (WHO, 2004). Rivers are of immense importance geologically, biologically, historically and culturally. Although they contain only about and nutrients to areas all around the earth. They are

\section{Author's Address}

${ }^{1}$ Department of Environmental Engineering, SITE, Subharti University, Meerut - 250004

${ }^{2}$ Limnology and Ecological Modelling Laboratory, Department of Zoology \& Environmental Sciences, GKV

E-mail:varun1815@gmail.com
$0.0001 \%$ of the total amount of water in the world at any given time, rivers is vital carriers of water critical components of the hydrological cycle, acting as drainage channels for surface water - the world's rivers drain nearly $75 \%$ of the earth's land surface. Various factors like temperature, turbidity, nutrients, hardness, alkalinity and dissolved oxygen play an important role for the growth of plants and animals in water body, on the other hand biological oxygen demand indicate the pollution level of the water body (Kamal et al., 2007; Ruhela et al.,2017 ). It is estimated that community waste from human activities accounts for four times as much wastewater as industrial effluents, most of which is discharged untreated/partially treated into the water courses in India (Sahu, 2005). They are prime factors controlling the global water cycle and in the hydrologic cycle, they are the most dynamic agents of transport. The quality and quantity of surface water in a river basin is influenced by natural factors such as rainfall, temperature and anthropogenic changes that curtail natural flow of the river, or alter its hydrochemistry (US EPA, 2009) Study area: Uttarakhand is a state located in the northern part of India. It extends from $28^{\circ} 43^{\prime} \mathrm{N}$ to $31^{\circ} 27^{\prime} \mathrm{N}$ longitude and $77^{\circ} 34^{\prime}$ east to $81^{\circ} 02^{\prime} \mathrm{E}$ 
latitude. Haridwar district, covering an area of about $2360 \mathrm{~km}^{2}$, is in the southwestern part of Uttarakhand state of India. Its latitude and longitude are 29.96 degree north and 78.16 degree east respectively.

\section{Sampling Sites}

For the analytical work of physico-chemical parameter of the river Ganga the sampling network was designed to cover a wide range of determinants characteristics at selected sites. Four sampling sites were selected in the river Ganga.

Sampling sites 1: Parmarth Niketan (Rishikesh): This site is situated near the parmarth niketan ashram, Rishikesh

Sampling sites 2: Har ki pauri: This site is situated on right side of the platform of clock tower of Har ki Pauri.

Sampling sites 3: Prem Nagar Ashram Ghat: This site is situated behind the Prem Nagar Ashram. Sampling sites 4: Jatwara Bridge: This site is situated on left side of the Jatwara Pul.

\section{Material and Methods}

Analysis of water samples were done according to standard methods as prescribed in APHA (2017), and Khanna and Bhutiani (2007). Samples were collected at 7 a.m to 10 a.m and were bottled in jerry cans and immediately transferred to laboratory for the analysis. Water Quality Index (WQI) was calculated by using the Weighted Arithmetic Index method as described by (Cude, 2001, Brown et al., 1970). In this model, different water quality components are multiplied by a weighting factor and are then aggregated using simple arithmetic mean.

\section{Results \& Discussion}

Site wise observations for various Physicochemical parameters are given in fig(1.1 to 1.12).

\section{Sampling site I}

Water temperature $\left({ }^{\circ} \mathrm{C}\right)$ : minimum of $10.98{ }^{\circ} \mathrm{C}$ in the February and maximum of $13.73{ }^{\circ} \mathrm{C}$ in the month of April and average value was found $12.47^{\circ} \mathrm{C} \pm 1.1$.

Total solids (mg/l): minimum $600 \mathrm{mg} / \mathrm{l}$ in the month of March and maximum of $920 \mathrm{mg} / \mathrm{l}$ in the month of April and average value was found 774 $\mathrm{mg} / \mathrm{l} \pm 104.90$.
Total dissolved solid (mg/l): minimum $350 \mathrm{mg} / \mathrm{l}$ in the month of March and maximum of $600 \mathrm{mg} / \mathrm{l}$ in the month of February and average value was found $469.5 \mathrm{mg} / \mathrm{l} \pm 94.71$.

Total suspended solid (mg/l): minimum $200 \mathrm{mg} / \mathrm{l}$ in the month of February and maximum of 445 $\mathrm{mg} / \mathrm{l}$ in the month of April and average value was found $304.5 \mathrm{mg} / \mathrm{l} \pm 85.52$.

pH: minimum 7.3 in the month of April and maximum of 7.5 in the month of February and average value was found $7.44 \pm 0.07$.

Dissolved Oxygen: Minimum $8.98 \mathrm{mg} / \mathrm{l}$ in the month of April and maximum of $10.85 \mathrm{mg} / \mathrm{l}$ in the month of February and average value was found $9.84 \mathrm{mg} / 1 \pm 0.63$.

Biochemical Oxygen Demand (BOD) minimum $1.33 \mathrm{mg} / \mathrm{l}$ in the month of February and maximum of 3.66 in the month of March and average value was found $2.44 \mathrm{mg} / \mathrm{l} \pm 0.91$.

Chemical Oxygen Demand (COD): minimum $7.50 \mathrm{mg} / \mathrm{l}$ in the month of April and maximum of $11.50 \mathrm{mg} / \mathrm{l}$ in month and average value was found $8.74 \mathrm{mg} / \mathrm{l} \pm 1.12$.

Free CO2: minimum $7.7 \mathrm{mg} / \mathrm{l}$ in the month of February and maximum of $17.6 \mathrm{mg} / \mathrm{l}$ in the month of April and average value was found $12.1 \mathrm{mg} / \mathrm{l} \pm$ 3.36.

Alkalinity: minimum $50 \mathrm{mg} / \mathrm{l}$ in the month of April and maximum of $80 \mathrm{mg} / \mathrm{l}$ in the month of February and average value was found $56.5 \mathrm{mg} / \mathrm{l} \pm 11.56$.

Acidity: minimum $22.50 \mathrm{mg} / \mathrm{l}$ in the month of February and maximum of $115 \mathrm{mg} / \mathrm{l}$ in the month of April and average value was found $63 \mathrm{mg} / \mathrm{l} \pm$ 34.50.

Chloride: minimum $10.65 \mathrm{mg} / \mathrm{l}$ in the month of March and maximum of 15.62 in the month of April and average value was found $14.41 \mathrm{mg} / \mathrm{l} \pm$ 1.80.

Total Hardness: minimum $201.0 \mathrm{mg} / \mathrm{l}$ in the month of April and maximum of $292.0 \mathrm{mg} / \mathrm{l}$ in the month of March and average value was found 257.0 $\mathrm{mg} / \mathrm{l} \pm 32.8$.

Calcium: minimum $56.11 \mathrm{mg} / \mathrm{l}$ in the month of April and maximum of $76.15 \mathrm{mg} / \mathrm{l}$ in the month of March and average value was found $67.13 \mathrm{mg} / \mathrm{l} \pm$ 6.43.

Magnesium: minimum $35.53 \mathrm{mg} / \mathrm{l}$ in the month of April and maximum of $53.15 \mathrm{mg} / \mathrm{l}$ in the month of February and average value was found $46.14 \mathrm{mg} / \mathrm{l} \pm$ 6.93. 


\section{Sampling site II}

Water temperature $\left({ }^{\circ} \mathrm{C}\right)$ : minimum of $10.86{ }^{\circ} \mathrm{C}$ in the month of February and maximum of $13.86{ }^{\circ} \mathrm{C}$ in the month of April and average value was found $12.76^{\circ} \mathrm{C} \pm 1.2$.

Total solids (mg/l): minimum $420 \mathrm{mg} / \mathrm{l}$ in the month of March and maximum of $950 \mathrm{mg} / \mathrm{l}$ in the month of April and average value was found 758.5 $\mathrm{mg} / \mathrm{l} \pm 160.94$.

Total dissolved solid (mg/l): minimum $200 \mathrm{mg} / \mathrm{l}$ in the month of March and maximum of $690 \mathrm{mg} / \mathrm{l}$ in the month of February and average value was found $469 \mathrm{mg} / \mathrm{l} \pm 143.47$.

Total suspended solid (mg/l): minimum $200 \mathrm{mg} / \mathrm{l}$ in the month of February and maximum of 450 $\mathrm{mg} / \mathrm{l}$ in the month of April and average value was found $289.50 \mathrm{mg} / \mathrm{l} \pm 82.27$.

pH: minimum 7.1 in the month of March and maximum of 7.4 in the month of February and average value was found $7.26 \pm 0.08$.

Dissolved Oxygen: minimum $9.82 \mathrm{mg} / \mathrm{l}$ in the month of April and maximum of $10.6 \mathrm{mg} / \mathrm{l}$ in the month of March and average value was found 10.14 $\mathrm{mg} / \mathrm{l} \pm 0.21$.

Biochemical Oxygen Demand (BOD): minimum $1.08 \mathrm{mg} / \mathrm{l}$ in the month of April and maximum of $2.63 \mathrm{mg} / \mathrm{l}$ in the month of March and average value was found $1.60 \mathrm{mg} / 1 \pm 0.47$.

Chemical Oxygen Demand (COD): minimum $8.20 \mathrm{mg} / \mathrm{l}$ in the month of April and maximum of 10.50 in month of February and average value was found $8.84 \mathrm{mg} / \mathrm{l} \pm 0.75$.

Free CO2: minimum $6.6 \mathrm{mg} / \mathrm{l}$ in the month of February and maximum of $18.7 \mathrm{mg} / \mathrm{l}$ in the month of April and average value was found $12.32 \mathrm{mg} / \mathrm{l} \pm$ 4.2.

Alkalinity: minimum $35 \mathrm{mg} / \mathrm{l}$ in the month of March and maximum of $60 \mathrm{mg} / \mathrm{l}$ in the month of February and average value was found $48.5 \mathrm{mg} / \mathrm{l} \pm$ 10.01 .

Acidity minimum $25 \mathrm{mg} / \mathrm{l}$ in the month of February and maximum of $100 \mathrm{mg} / \mathrm{l}$ in the month of March and average value was found $58.25 \mathrm{mg} / \mathrm{l} \pm 23.86$.

Chloride: minimum of $19.80 \mathrm{mg} / \mathrm{l}$ in the month of February and maximum of $12.78 \mathrm{mg} / \mathrm{l}$ in the month of April and average value was found $15.26 \mathrm{mg} / \mathrm{l} \pm$ 2.33 .

Total Hardness: minimum of $195 \mathrm{mg} / \mathrm{l}$ in the month of April and maximum of $380 \mathrm{mg} / \mathrm{l}$ in the month of February and average the value was found $290.2 \mathrm{mg} / \mathrm{l} \pm 63.36$.

Calcium: minimum of $60.12 \mathrm{mg} / \mathrm{l}$ in the month of April and maximum of 90.18 in the month of March and average value was found $71.33 \mathrm{mg} / \mathrm{l} \pm$ 11.06.

Magnesium: minimum of $31.93 \mathrm{mg} / \mathrm{l}$ in the month of April and maximum of $73.16 \mathrm{mg} / \mathrm{l}$ in the month of $73.16 \mathrm{mg} / \mathrm{l}$ and average value was found 53.45 $\mathrm{mg} / \mathrm{l} \pm 13.84$.

\section{Sampling site III}

Water temperature $\left({ }^{\circ} \mathbf{C}\right)$ : minimum of $10.8^{\circ} \mathrm{C}$ in the month of February and maximum of $13.9^{\circ} \mathrm{C}$ in the month of March and average value was found $12.82{ }^{\circ} \mathrm{C} \pm 1.26$

Total solids (mg/l): minimum $600 \mathrm{mg} / \mathrm{l}$ in the month of March and maximum of $1000 \mathrm{mg} / \mathrm{l}$ in the month of February and average value was found $829 \mathrm{mg} / \mathrm{l} \pm 118.27$.

Total dissolved solid (mg/l): minimum $400 \mathrm{mg} / \mathrm{l}$ in the month of March and April and maximum of 650 $\mathrm{mg} / \mathrm{l}$ in the month of February and the average value was found $492.5 \mathrm{mg} / \mathrm{l} \pm 104.12$.

Total suspended solid (mg/l): minimum $200 \mathrm{mg} / \mathrm{l}$ in the month of February and maximum of 475 $\mathrm{mg} / \mathrm{l}$ in the month of April and the average value was found $336.5 \mathrm{mg} / \mathrm{l} \pm 96.31$.

pH: minimum 7.1 in the month of March and maximum of 7.7 in the month of February and average value was found $7.36 \pm 0.21$.

Dissolved Oxygen: minimum $9.2 \mathrm{mg} / \mathrm{l}$ in the month of April and maximum of $10.07 \mathrm{mg} / \mathrm{l}$ in the month of February and average value was found $9.69 \mathrm{mg} / \mathrm{l} \pm 0.26$.

Biochemical Oxygen Demand (BOD): minimum $1.40 \mathrm{mg} / \mathrm{l}$ in the month of February and maximum of 2.45 in the month of March and average value was found $1.90 \mathrm{mg} / \mathrm{l} \pm 0.30$.

Chemical Oxygen Demand (COD): minimum $5.50 \mathrm{mg} / \mathrm{l}$ in the month of February and maximum of $9.20 \mathrm{mg} / \mathrm{l}$ in the month of April and average value was found $8.0 \mathrm{mg} / \mathrm{l} \pm 1.26$.

Free $\mathrm{CO}_{2}:$ minimum $7.7 \mathrm{mg} / \mathrm{l}$ in the month of April and maximum of $19.8 \mathrm{mg} / \mathrm{l}$ in the month of March and average value was found $14.85 \mathrm{mg} / \mathrm{l} \pm 4.70$.

Alkalinity: minimum $40 \mathrm{mg} / \mathrm{l}$ in the month of March and maximum of $60 \mathrm{mg} / \mathrm{l}$ in the month of February and average value was found $49.0 \mathrm{mg} / \mathrm{l} \pm$ 6.15 . 
Acidity: minimum $22.5 \mathrm{mg} / \mathrm{l}$ in the month of February and maximum of $115 \mathrm{mg} / \mathrm{l}$ in the month of April and average value was found $61.25 \mathrm{mg} / \mathrm{l} \pm$ 31.16.

Chloride: minimum of $12.78 \mathrm{mg} / \mathrm{l}$ in the month of March and maximum of $19.90 \mathrm{mg} / \mathrm{l}$ in the month of February and average value was found $15.6 \mathrm{mg} / \mathrm{l} \pm$ 2.21 .

Total Hardness: minimum $228 \mathrm{mg} / \mathrm{l}$ in the month of April and maximum of $361 \mathrm{mg} / \mathrm{l}$ in the month of March and average value was found $293.8 \mathrm{mg} / \mathrm{l} \pm$ 40.16 .

Calcium: minimum of $60.12 \mathrm{mg} / \mathrm{l}$ in the month of February and maximum of $84.16 \mathrm{mg} / \mathrm{l}$ in the month of March and average value was found $73.95 \mathrm{mg} / 1$ +7.10 .

Magnesium: minimum of $37.04 \mathrm{mg} / \mathrm{l}$ in the month of April and maximum of $69.01 \mathrm{mg} / \mathrm{l}$ in the month of March and average value was found $53.64 \mathrm{mg} / \mathrm{l}$ \pm 9.55 .

\section{Sampling site IV}

Water temperature $\left({ }^{\circ} \mathrm{C}\right)$ : minimum of $10.92{ }^{\circ} \mathrm{C}$ in the month of February and maximum of $13.5^{\circ} \mathrm{C}$ in the month of April and average value was found $12.59{ }^{\circ} \mathrm{C} \pm 0.94$

Total solids (mg/l): minimum $400 \mathrm{mg} / \mathrm{l}$ in the month of February and maximum of $850 \mathrm{mg} / \mathrm{l}$ in the month of April and average value was found $693 \mathrm{mg} / \mathrm{l} \pm 185.12$.

Total dissolved solid (mg/l): minimum $200 \mathrm{mg} / \mathrm{l}$ in the month of February and maximum of $525 \mathrm{mg} / \mathrm{l}$ in the month of April and average value was found $382 \mathrm{mg} / \mathrm{l} \pm 119.22$.

Total suspended solid (mg/l): minimum of 200 $\mathrm{mg} / \mathrm{l}$ in the month of March and February and maximum of $400 \mathrm{mg} / \mathrm{l}$ in the month of April and the average value was found $311 \mathrm{mg} / \mathrm{l} \pm 73.29$.

pH: minimum 7.1 in the month of February and March and maximum of 7.5 in the month of April and average value was found $7.24 \pm 0.15$.

Dissolved Oxygen: minimum $9.53 \mathrm{mg} / \mathrm{l}$ in the month of April and maximum of $10.4 \mathrm{mg} / \mathrm{l}$ in the month of Febraury and average value was found $9.73 \mathrm{mg} / \mathrm{l} \pm 0.35$.

Biochemical Oxygen Demand (BOD): minimum $1.08 \mathrm{mg} / \mathrm{l}$ in the month of April and maximum of $2.91 \mathrm{mg} / \mathrm{l}$ in the month of February and average value was found $1.92 \mathrm{mg} / \mathrm{l} \pm 0.64$.
Chemical Oxygen Demand (COD): minimum $8.30 \mathrm{mg} / \mathrm{l}$ in the month of April and maximum of $11.0 \mathrm{mg} / \mathrm{l}$ in the month of February and average value was found $9.18 \mathrm{mg} / \mathrm{l} \pm 0.94$.

Free $\mathrm{CO}_{2}$ : minimum $9.9 \mathrm{mg} / \mathrm{l}$ in the month of February and maximum of $23.10 \mathrm{mg} / \mathrm{l}$ in the month of March and average value was found $15.62 \mathrm{mg} / \mathrm{l}$ \pm 4.17 .

Alkalinity: minimum $30 \mathrm{mg} / \mathrm{l}$ in the month of March and maximum of $65 \mathrm{mg} / \mathrm{l}$ in the month of April and average value was found $48.7 \mathrm{mg} / \mathrm{l} \pm$ 11.22.

Acidity: minimum $27.5 \mathrm{mg} / \mathrm{l}$ in the month of February and maximum of $102.5 \mathrm{mg} / \mathrm{l}$ in the month of March and average value was found $58.5 \mathrm{mg} / \mathrm{l} \pm$ 22.71.

Chloride: minimum $11.36 \mathrm{mg} / \mathrm{l}$ in the month of April and maximum of $22.01 \mathrm{mg} / \mathrm{l}$ in the month of February and average value was found $15.90 \mathrm{mg} / \mathrm{l} \pm$ 3.42 .

Total Hardness: minimum $216 \mathrm{mg} / \mathrm{l}$ in the month of April and maximum of $339 \mathrm{mg} / \mathrm{l}$ in the month of March and average value was found $290.3 \mathrm{mg} / \mathrm{l} \pm$ 42.01 .

Calcium: minimum of $70.14 \mathrm{mg} / \mathrm{l}$ in the month of February and April and maximum of $82.16 \mathrm{mg} / \mathrm{l}$ in the month of March and average value was found $75.15 \mathrm{mg} / \mathrm{l} \pm 4.04$.

Magnesium: minimum $35.10 \mathrm{mg} / \mathrm{l}$ in the month of April and maximum of $63.15 \mathrm{mg} / \mathrm{l}$ in the month of February and average value was found $52.44 \mathrm{mg} / \mathrm{l} \pm$ 9.68 .

\section{Water Quality Index (WQI)}

In current study, Water Quality Index (WQI) was calculated by using the Weighted Arithmetic Index method as described by (Cude, 2001, Brown et al., 1970). In this model, different water quality components are multiplied by a weighting factor and are then aggregated using simple arithmetic mean. For assessing the quality of water in this study, firstly, the quality rating scale (Qi) for each parameter was calculated by using the following equation;

$$
\mathrm{Qn}=100[\mathrm{Vn}-\mathrm{Vi}] /[\mathrm{Sn}-\mathrm{Vi}]
$$

Where:

qn=Quality rating for the nth water quality parameter,

Vn=Estimated value of the nth water quality parameters of collected sample, 


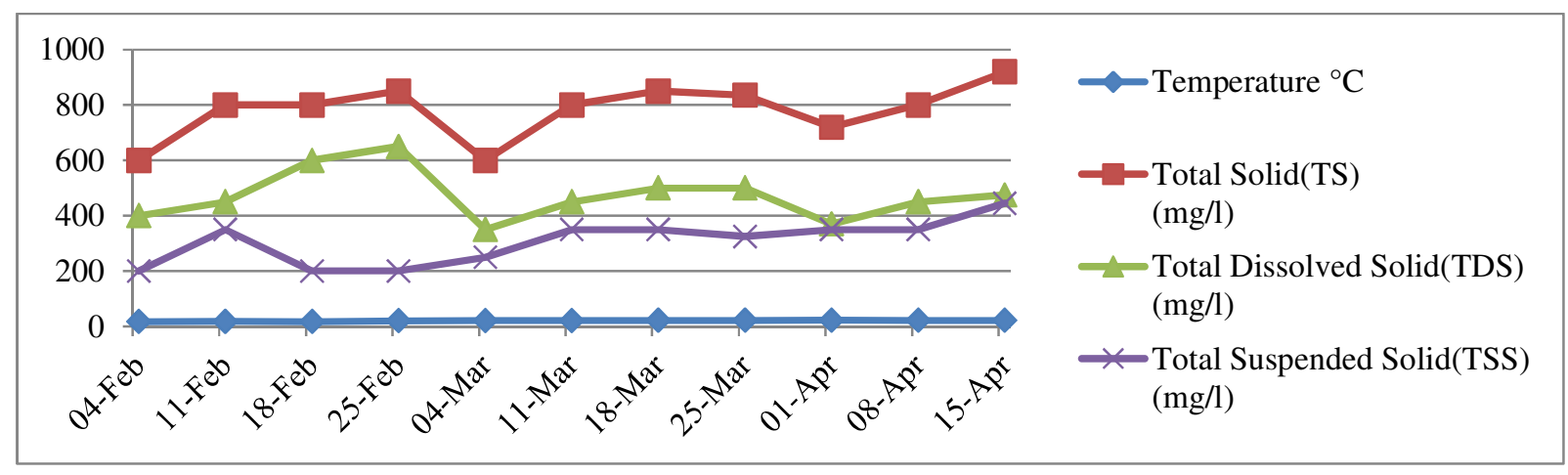

Fig. 1.1: Showing variation in physical parameter at Site I

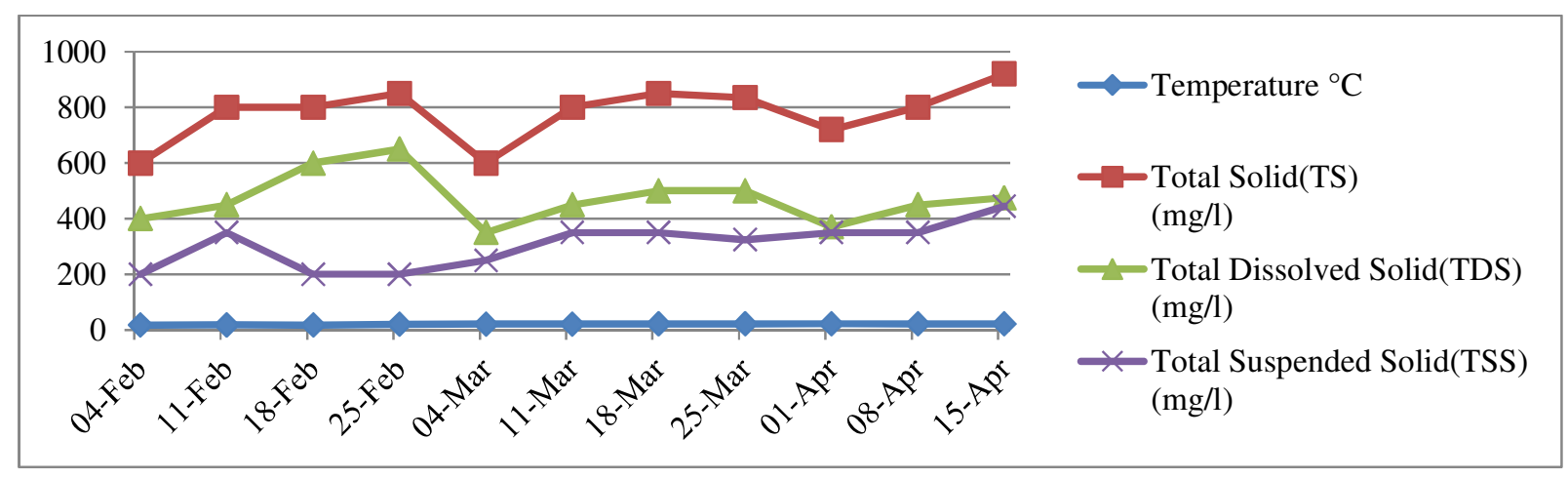

Fig. 1.2: Showing variation in physical parameter at Site II

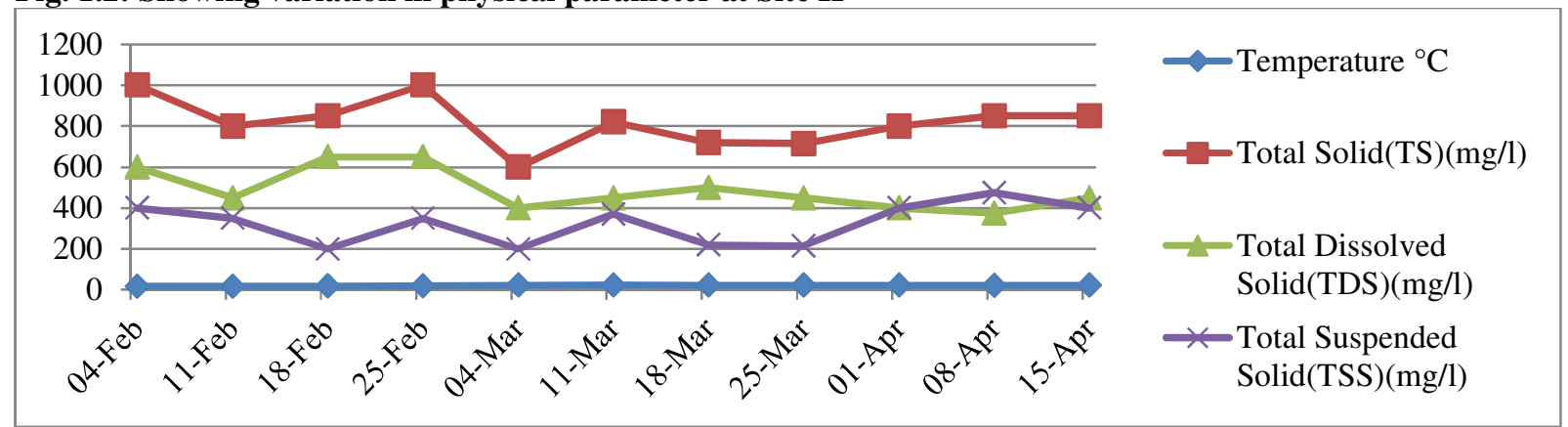

Fig. 1.3: Showing variation in physical parameter at Site III

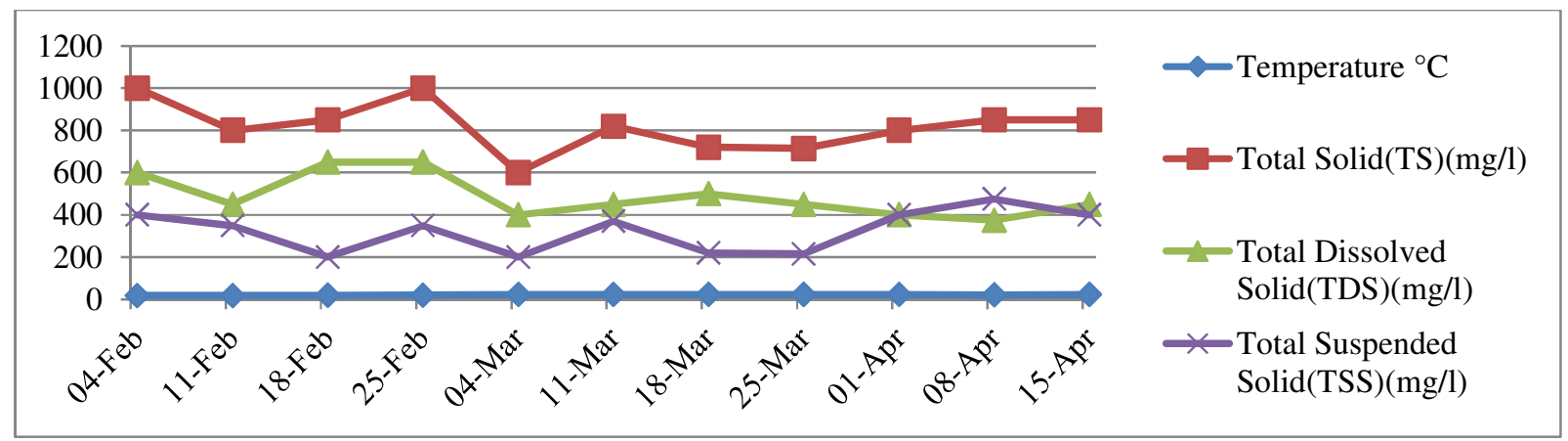

Fig. 1.4: Showing variation in physical parameter at Site IV 


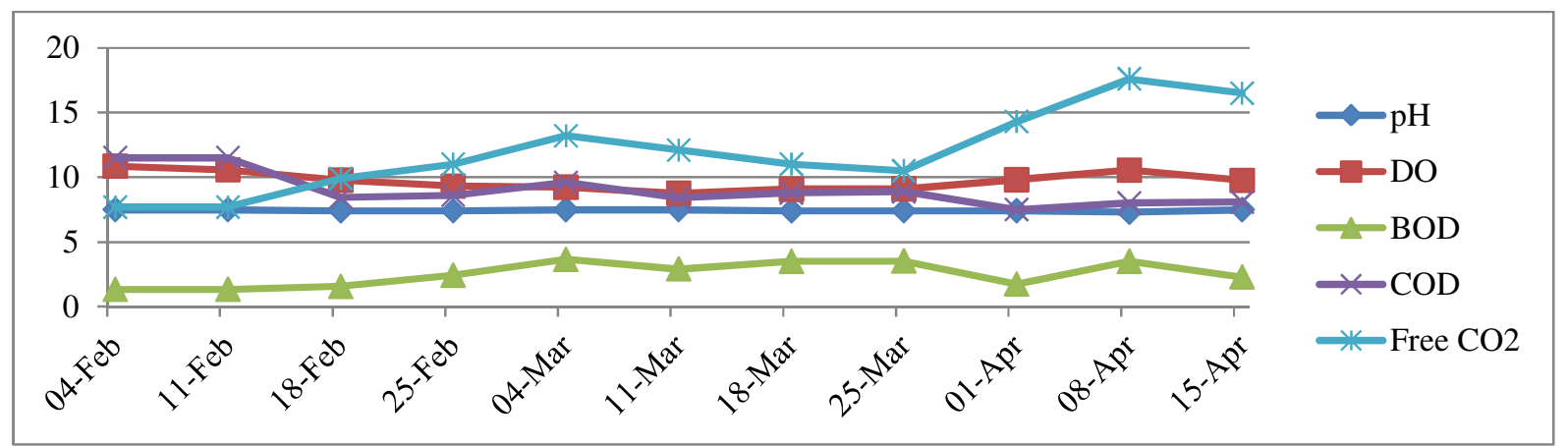

Fig 1.5.: Showing variation in Chemical Parameter at Sampling Site I contd.

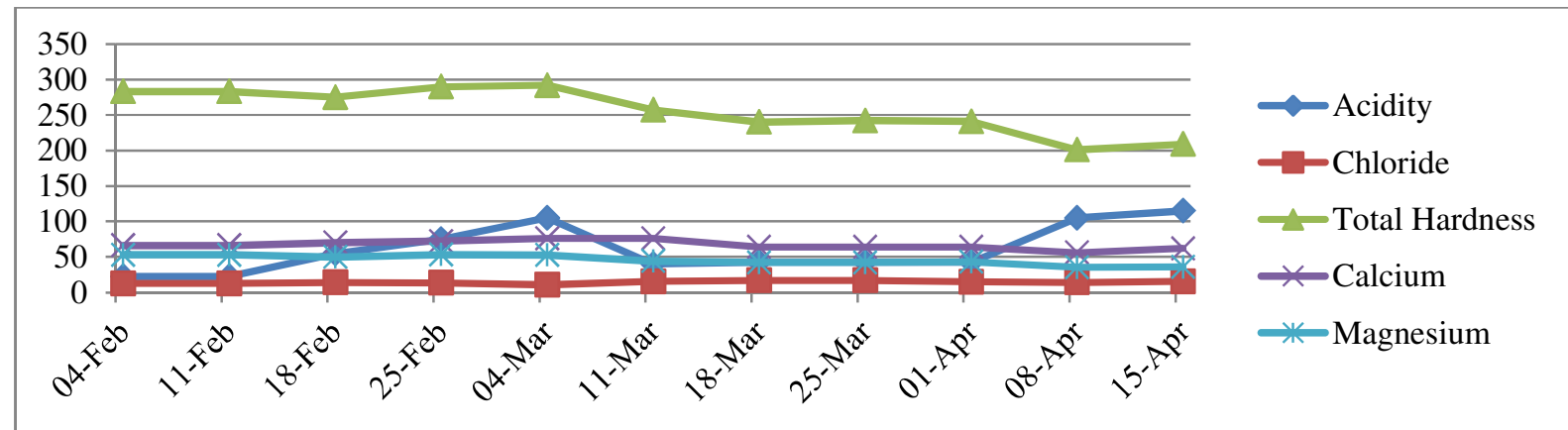

Fig 1.6.: Showing variation in Chemical Parameter at Sampling Site I

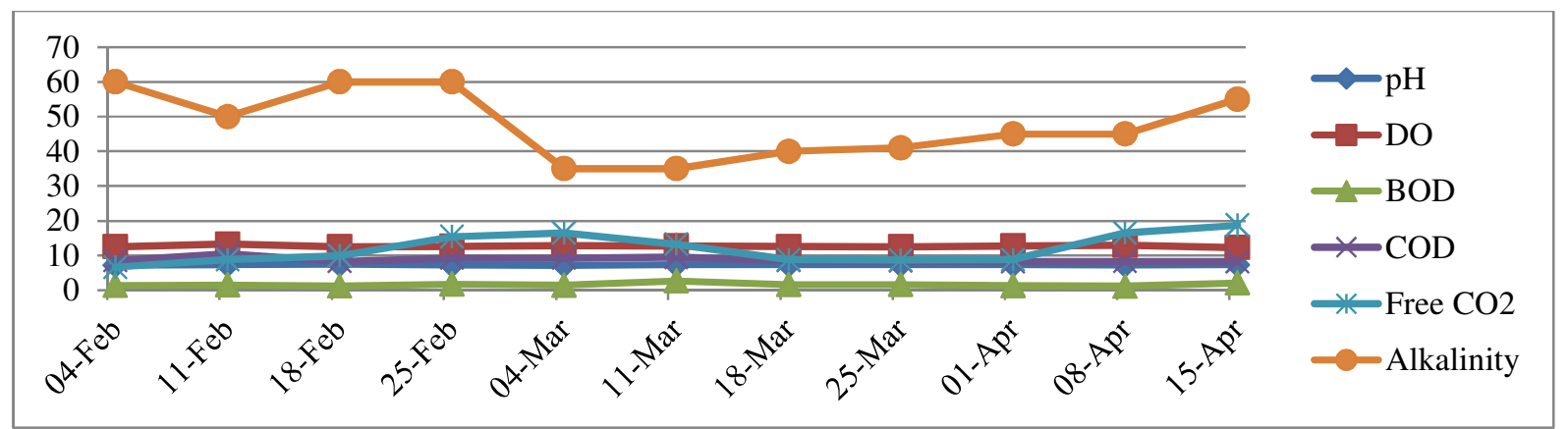

Fig 1.7.: Showing variation in Chemical Parameter at Sampling Site II contd.

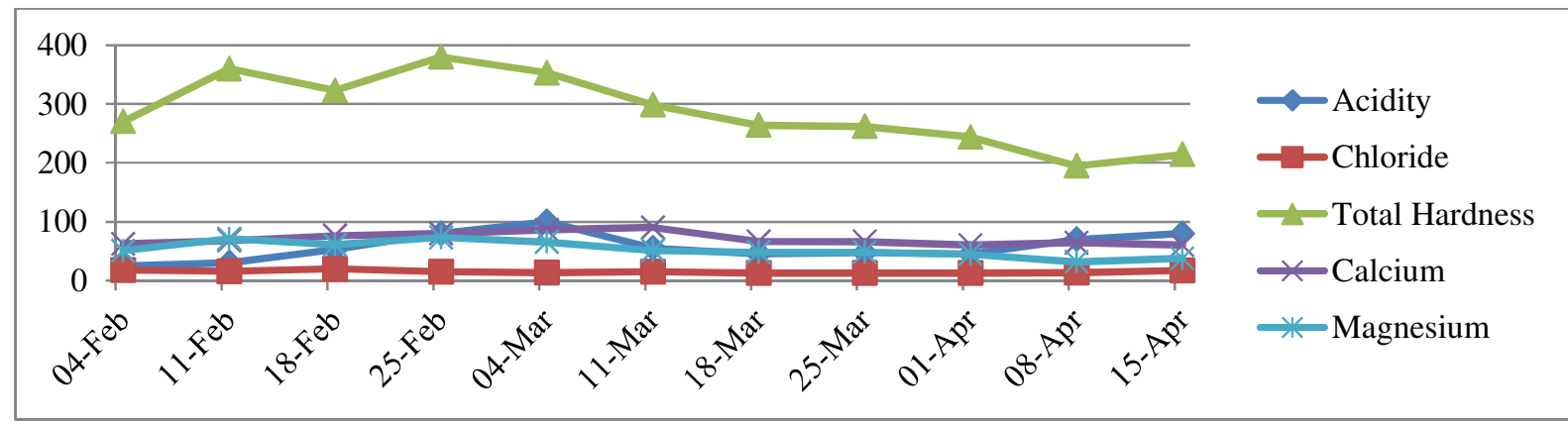

Fig 1.8.: Showing variation in Chemical Parameter at Sampling Site II 


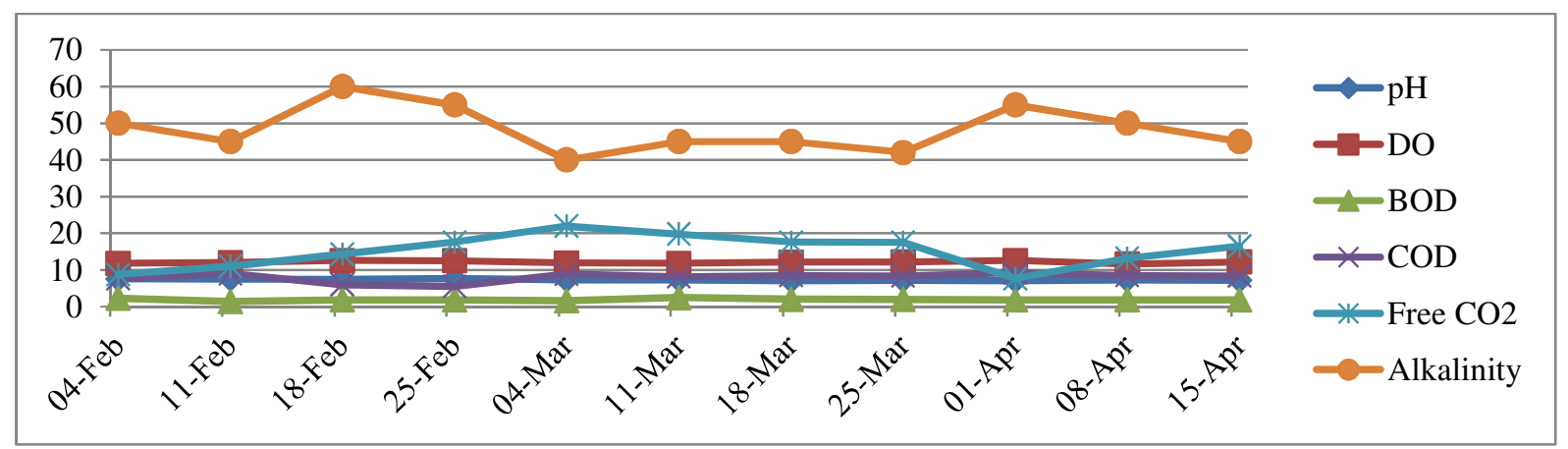

Fig 1.9.: Showing variation in Chemical Parameter at Sampling Site III contd.

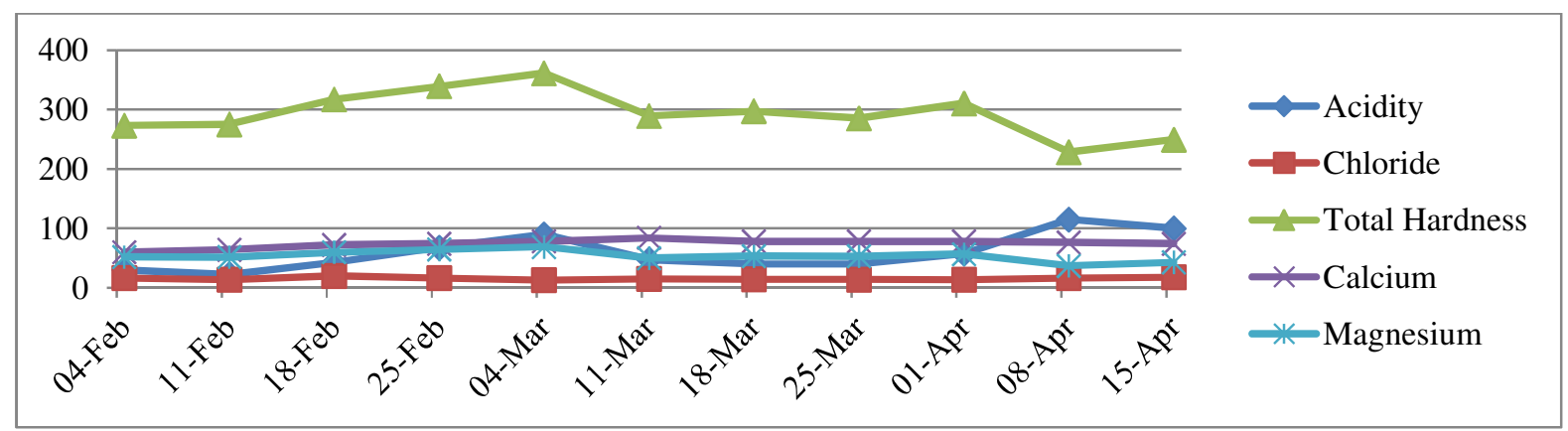

Fig 1.10.: Showing variation in Chemical Parameter at Sampling Site III

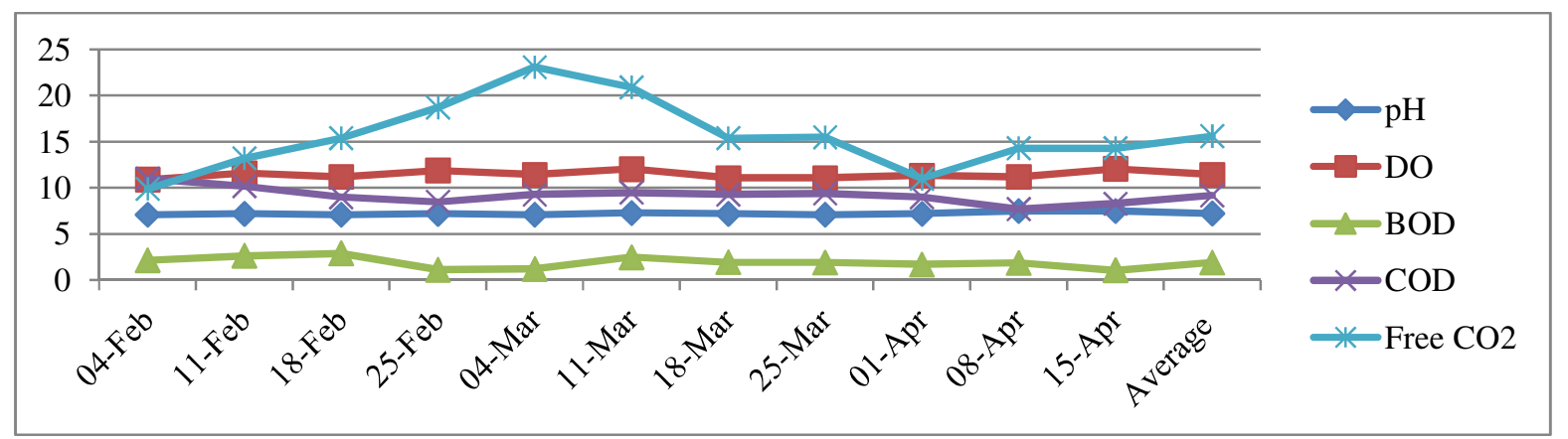

Fig 1.11.: Showing variation in Chemical Parameter at Sampling Site IV contd.

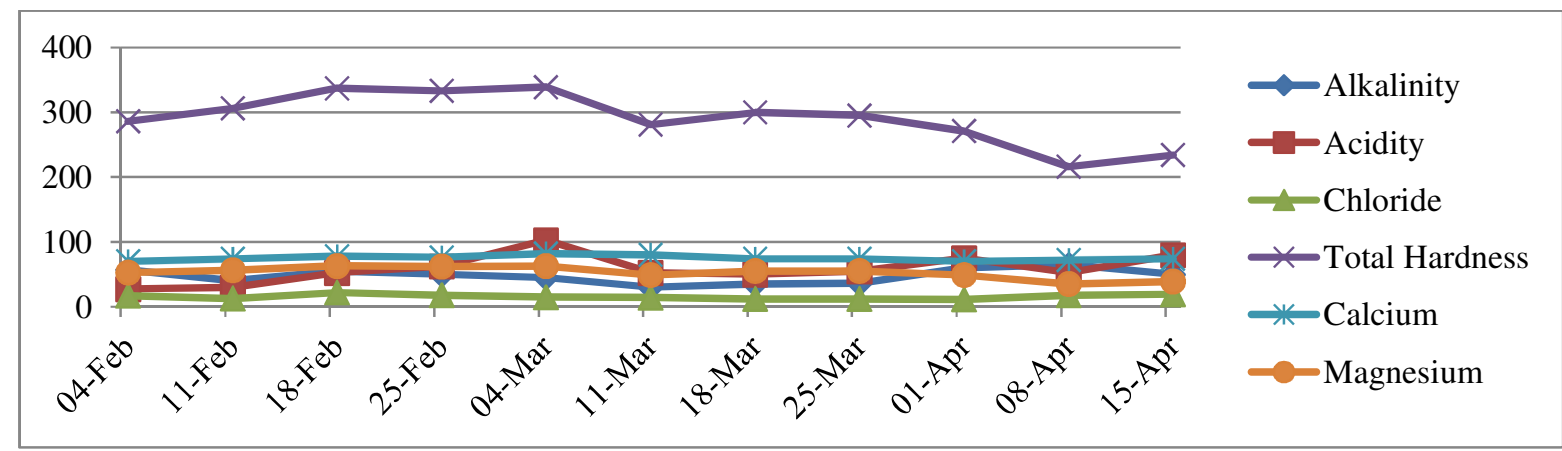

Fig 1.12.: Showing variation in Chemical Parameter at Sampling Site IV 
$\mathrm{Sn}=$ Standard permissible value of the nth water quality parameter,

$\mathrm{Vi} 0=$ Ideal value of the nth water quality parameter in pure water. (i.e. 0 for all other parameters except the parameter $\mathrm{pH}$ and Dissolved oxygen (7 and 14.6 $\mathrm{mg} / \mathrm{L}$ respectively.) (Let there be $\mathrm{n}$ water quality parameters and quality rating or sub index (qn) corresponding to nth parameter is a number reflecting the relative of this parameter in polluted water with respect to its standard permissible value.) Unit weight was calculated by a value inversely proportional to the recommended standard value $\mathrm{Sn}$ of the corresponding parameter.

Where:

$$
\mathrm{WQI}=\Sigma \mathrm{qnWn} / \Sigma \mathrm{Wn}
$$

$\mathrm{Wn}=$ Unit weight for $\mathrm{nth}$ water quality parameter, $\mathrm{Sn}=$ Standard permissible value of the nth water quality parameter,

$\mathrm{K}=$ Constant for proportionality.

The overall WQI was calculated by aggregating the quality rating with the unit weight linearly.

WQI of the River during the study period was 46.03 which fall in the good water quality.

Table 1. Water Quality Index (WQI) and its status

\begin{tabular}{|l|l|}
\hline $\begin{array}{l}\text { Water quality Index } \\
\text { Level }\end{array}$ & Water Quality Status \\
\hline $0-25$ & Excellent water quality \\
\hline $26-50$ & Good water quality \\
\hline $51-75$ & Poor water quality \\
\hline $76-100$ & Very poor water quality \\
\hline$>100$ & Unsuitable for drinking \\
\hline
\end{tabular}

\section{Discussion}

The index result represents the level of water quality in a given water basin, such as lake, river or stream. A number of workers all over the world developed WQI based on rating of different water quality parameters. For the evaluation of water quality, WQI was applied to the river water (Abbasi et al., 2012, Ahmad et al., 2012, Alam, 2010, Chauhhan and Singh, 2010, Balan et al., 2012, Chowdhury et al, 2012, Tyagi et al, 2013, Lumb et $a l$, 2006). During the study period WQI of the River indicated good water quality.
Water temperature plays an important factor which influences the chemical, bio-chemical characteristics of water body. In the present study an average fluctuation of water temperature was observed $18.10^{\circ} \mathrm{C} \pm 0.08$ (minimum) at 04-Feb-2018 and $22.65^{\circ} \mathrm{C} \pm 0.51$ (maximum) at 02-April-2018. Total average value of temperature was recorded $20.93^{\circ} \mathrm{C} \pm 1.88$. A more or less tend has been observed in the Mothronwala swamp, by Gupta (2008).

Total solids were recorded average at $763.63 \mathrm{mg} / \mathrm{l} \pm$ 113.8. Minimum average value of total solids were observed on 04-March-2018 (517.50mg/1 \pm 96.05) and maximum at $26-\mathrm{Feb}-2018(897 \mathrm{mg} / \mathrm{l} \pm 70.89)$.

Total solid is term applied to all matter except the water contained in liquid materials. Total solids cause ecological imbalance in the aquatic ecosystem by mechanical abrasive action. Same trends were also reported by Yadav and Srivastava (2011). Fouzia et al., (2012) and Bhutiani et al., (2017) were observed similar trend in Tons river.

The total average value of total dissolved solids $453.25 \mathrm{mg} / \mathrm{l} \pm$ 91.36. The total dissolved solids recorded to be minimum at 04-March-2018 $(292.5 \mathrm{mg} / \mathrm{l} \pm$ 97.77) and maximum was recorded at 26-Feb-2018(622.5mg/l 83.82$)$. Bera et al. (2012); Bhutiani et al., (2018) were observed similar trends at Brahmani River Water. A more or less same trend was observed by Khanna et al., 2014; Bhutiani et al., 2017 and Bhutiani et al., 2018.

$\mathrm{pH}$ affects the dissolved oxygen level in the water, photosynthesis of aquatic plants, metabolic rates of aquatic organisms. Most rivers have a neutral to slightly basic $\mathrm{pH}$ of 6.5 to 8.5 . The monthly average value of $\mathrm{pH}$ was observed $7.33 \pm 0.06$. The $\mathrm{pH}$ was recorded to be minimum at 17-March-2018 (7.25 \pm 0.13$)$ and maximum was recorded at 26Feb-2018 (7.38 \pm 0.24). Gupta et.al (2008) observed $\mathrm{pH}$ in Mothronwala swamp, and found more or less similar trends in their study. Same trend were also reported by Dhaka and Minakshi (2011). DO values indicate the degree of pollution in water bodies. Dissolved oxygen was quite high and showed wide fluctuation. Maximum dissolved oxygen was recorded at 26-Feb-2018 $(11.14 \mathrm{mg} / \mathrm{l} \pm$ 0.39 ) and the minimum value of dissolved oxygen was observed at 20 -Feb-2018 $(9.30 \mathrm{mg} / \mathrm{l} \pm 0.61)$. The total average value of dissolved oxygen was observed 10.22 \pm 0.76 . This trend was also observed by Fouzia and Amir (2012) in the river Tons. Same 54

Environment Conservation Journal 
trend is also reported by Khanna et al., (2003) and Bhutiani et al., (2016) in the Ganga river system in foothills, of Garhwal Himalaya. Sayeswara et al., (2011) also observed similar trend on Sominkoppa pond at Shivamagga, Karnataka. Kumar et al. (2010) was observed identical result in Beas river. Imnatoshi et al. (2012) observed DO in Doyang river at Nagaland and found more or less similar trends in their study.

BOD or biochemical oxygen demand represents the amount of oxygen that microbes need to stabilize biologically oxidizable matter. In the present study, maximum BOD was recorded at 11-March-2018 $(2.62 \mathrm{mg} / \mathrm{l} \pm 0.91)$ and the minimum value of BOD was recorded at 02-April-2018 $(1.64 \mathrm{mg} / \mathrm{l} \pm 0.24)$. The total average value of BOD was observed $1.96 \mathrm{mg} / \mathrm{l} \pm 0.76$. Same trends were of BOD have shown by Karla et al. (2012) in ground water taken from five blocks. Khanna et al, (2014), Bhutiani et al, (2017) was also observed same trend in limnological parameters.

COD determine the amount of organic pollutants found in surface water, making COD a useful measure of water quality. It is expressed in milligrams per liter $(\mathrm{mg} / \mathrm{l})$, which indicates the mass of oxygen consumed per liter of solution. The total average value of COD were noted $8.69 \mathrm{mg} / \mathrm{l} \pm$ 0.72 whereas, minimum average value was found at 20-Feb-2018 (7.94 mg/l \pm 1.33$)$ and maximum at 12-Feb-2018(10.30 mg/l \pm 1.03). Total average value of free Carbon dioxide was recorded 13.72 $\mathrm{mg} / \mathrm{l} \pm 3.37$. The minimum average value was found at 04-Feb-2018(8.25 mg/l \pm 1.42) and maximum average value was found at 04-March$2018(18.7 \mathrm{mg} / \mathrm{l} \pm 4.67)$. Alkalinity of water is a measure of weak acid present in it and of the cations balanced against them. Alkalinity may also increase due to decomposition of organic matter that has settled at the bottom.

Total Alkalinity in water is due to salts of weak acids and bicarbonates of highly alkaline water. Alkalinity values of 20-200 ppm are common in freshwater ecosystems. Total average value of alkalinity was recorded as $50.68 \mathrm{mg} / \mathrm{l} \pm 7.83$. The maximum average value of alkalinity was at 20 Feb-2018 (63.75 mg/l \pm 11.09) and the minimum was at 02-March-2018(40 mg/l \pm 4.08).Same trend is also reported by Khanna et al. (2012) in the Ganga river system in foothills, of Garhwal
Himalaya. The total average value of acidity was recorded $60.25 \mathrm{mg} / \mathrm{l} \pm 26.14$; whereas maximum average value was recorded at 15 -April-

$2018(93.75 \mathrm{mg} / \mathrm{l} \pm 17.02)$. and the minimum average value was at 12 -Feb-2018 (26.25 mg/l \pm 4.33). Same trend was found by Khanna and Bhutiani (2003).

Chlorides occur naturally in all types of water. High concentration of chloride is considered to be the indicators of pollution due to organic wastes of animal or industrial origin. Chlorides are troublesome in irrigation water and also harmful to aquatic life (Khan et al., 2012). Total average value of Chloride was recorded $15.28 \mathrm{mg} / \mathrm{l} \pm 1.96$, whereas maximum average value was recorded at 20-Feb-2018(18.98 mg/l \pm 3.34$)$ and the minimum average value was at 04-March-2018(12.96 mg/l \pm 1.78). Muhammad Naeem et al. (2011), Bhutiani \& Ahamad (2018) also observed same trend. Hardness is the property of water which prevents the lather formation with soap and increases the boiling points of water. Hardness of water mainly depends upon the amount of calcium or magnesium salts or both. The Hardness is a very important parameter in decreasing the toxic effect of poisonous element. Total average value of Total hardness was noted $282.7 \mathrm{mg} / \mathrm{l} \pm 42.06$ and the maximum average value of Hardness was at 04-March-2018(336.25 $\mathrm{mg} / \mathrm{l} \pm 30.87$ ) whereas, minimum average value was at 09-April-2018(210 mg/l \pm 14.90$)$ Fouzia and Amir (2012) observed Hardness in river Tons at Dehradun and found more or less similar trends in their study. Venkatesharaju et al., (2010); Malik and Kumar (2010) was also observed similar trend in ground water.

The total average value of Calcium was observed as $71.89 \mathrm{mg} / \mathrm{l} \pm 6.17$ and the maximum average value of Calcium was at 11-March-2018(82.66 mg/l \pm 5.98) whereas, minimum average value was at 04Feb-2018(64.13 mg/l \pm 4.33) Similar observation were also obtained by Srivastava et al.(2011) in river Ramganga. The considerable amount of magnesium influence water quality The total average value of Magnesium was observed as 51.42 $\mathrm{mg} / \mathrm{l} \pm 9.46$ and the maximum average value of Magnesium was at 26-Feb-2018(63.28 mg/l \pm 8.23) whereas, minimum average value was at 09-April$2018(34.9 \mathrm{mg} / \mathrm{l} \pm 2.15)$. 
Ruhela et al.

Table 2 Monthly average values for Physico-Chemical Parameter at Sampling Sites contd.

\begin{tabular}{|c|c|c|c|c|c|}
\hline SITES & Temperature ${ }^{\circ} \mathbf{C}$ & $\begin{array}{c}\text { Total Solid(TS) } \\
(\mathbf{m g} / \mathbf{l})\end{array}$ & $\begin{array}{c}\text { Total Dissolved } \\
\text { Solid(TDS) } \\
(\mathbf{m g} / \mathbf{l})\end{array}$ & $\begin{array}{c}\text { Total } \\
\text { Suspended } \\
\text { Solid(TSS) } \\
(\mathbf{m g} / \mathbf{l})\end{array}$ & $\mathbf{p H}$ \\
\hline Site I & 12.47 & 779.55 & 472.27 & 306.36 & 7.43 \\
\hline Site II & 12.76 & 762.27 & 474.55 & 287.73 & 7.26 \\
\hline Site III & 12.82 & 818.64 & 488.64 & 325.45 & 7.36 \\
\hline Site IV & 12.59 & 700.45 & 387.27 & 311.36 & 7.23 \\
\hline Average & 12.66 & 765.23 & 455.68 & 307.73 & 7.32 \\
\hline \pm SD & 0.16 & 49.20 & 46.18 & 15.59 & 0.09 \\
\hline
\end{tabular}

Table 2. Monthly average values for Physico-Chemical Parameter at Sampling Sites

\begin{tabular}{|c|c|c|c|c|c|c|c|c|c|c|}
\hline SITES & DO & BOD & COD & $\begin{array}{c}\text { Free } \\
\text { CO2 }\end{array}$ & Alkalinity & Acidity & Cl & $\begin{array}{c}\text { Total } \\
\text { Hardness }\end{array}$ & Ca & Mg \\
\hline Site I & 9.59 & 2.64 & 8.79 & 12.38 & 55.50 & 64.49 & 14.56 & 253.00 & 67.13 & 45.16 \\
\hline Site II & 10.14 & 1.60 & 8.80 & 11.99 & 47.82 & 57.23 & 15.03 & 287.64 & 70.86 & 52.96 \\
\hline Site III & 9.69 & 1.92 & 7.99 & 14.95 & 48.70 & 55.25 & 15.19 & 297.40 & 74.34 & 54.68 \\
\hline Site IV & 8.27 & 1.92 & 9.20 & 15.61 & 47.55 & 58.18 & 15.55 & 290.73 & 75.06 & 52.69 \\
\hline Avg. & 9.42 & 2.02 & 8.69 & 13.73 & 49.89 & 58.79 & 15.08 & 282.19 & 71.85 & 51.37 \\
\hline $\mathbf{\text { SD }}$ & 0.80 & 0.44 & 0.51 & 1.81 & 3.77 & 3.99 & 0.41 & 19.88 & 3.64 & 4.23 \\
\hline
\end{tabular}

Table 3. Calculation of WQI

\begin{tabular}{|l|l|l|l|l|l|l|}
\hline Parameters & $\begin{array}{l}\text { Observed } \\
\text { value } \\
(\mathbf{V o})\end{array}$ & $\begin{array}{l}\text { Standard } \\
\text { Value (Sn) }\end{array}$ & $\begin{array}{l}\text { Ideal } \\
\text { value }(\mathbf{V i})\end{array}$ & $\begin{array}{l}\text { unit wt(wn) } \\
=\mathbf{k} / \mathbf{S n}\end{array}$ & qn (QIty rating) & Wn*Qn \\
\hline TS(mg/l) & 764 & 2100 & 0 & 0.00 & 36.38 & 0.02 \\
\hline TDS(mg/l) & 453.25 & 500 & 0 & 0.00 & 90.65 & 0.18 \\
\hline TSS (mg/l) & 309.11 & 100 & 0 & 0.01 & 309.11 & 3.13 \\
\hline pH & 7.12 & 7.5 & 7 & 0.14 & 24.00 & 3.24 \\
\hline DO & 12.2 & 6 & 14.6 & 0.17 & 27.91 & 4.72 \\
\hline BOD & 1.97 & 5 & 0 & 0.20 & 39.40 & 7.99 \\
\hline COD & 8.7 & 250 & 0 & 0.00 & 3.48 & 0.01 \\
\hline Alkalinity & 50.68 & 200 & 0 & 0.01 & 25.34 & 0.13 \\
\hline Chloride & 15.29 & 250 & 0 & 0.00 & 6.12 & 0.02 \\
\hline $\begin{array}{l}\text { Total } \\
\text { Hardness }\end{array}$ & 282.83 & 300 & 0 & 0.00 & 94.28 & 0.32 \\
\hline Ca Hardness & 71.9 & 75 & 0 & 0.01 & 95.87 & 1.30 \\
\hline Mg Hardness & 51.42 & 30 & 0 & 0.03 & 171.40 & 5.79 \\
\hline & & & & $\Sigma \mathrm{Wn}=0.58$ & $\Sigma \mathrm{Qn}=923.93$ & $\Sigma \mathrm{Wn} * \mathrm{Qn}=26.86$ \\
\hline
\end{tabular}




\section{Conclusion}

The basic aim of WQI is to give a single value to the water quality of a source on the basis of one or the other system which translates the list of constituents and their concentrations present in a sample in to a single value. The index result represents the level of water quality in a given water basin, such as lake, river or stream. During the study period the water quality status of the river was found good, however steps for the cleanliness and implementation of various laws related to River Ganga must be monitored regularly.

\section{Acknowledgment}

The authors thank Department of Environmetnal Sciences, SITE, Subharti University, Meerut for the instrumentation facility during the analysis of parameters.

\section{References}

Abbasi SA, Arya DS, Ahmed AS, Abbasi N (1996) Water quality of a typical river Punnapuzha of Kerala. Pollut Res 15(2):163-166.

Ahmad IK, Salih NM, Nzar YH (2012) Determination of water quality index (WQI) for Qalyasan stream in Sulaimani city Kurdistan region of Iraq. Int J Plant Anim Environ Sci 2(4):148-157.

Alam M, Pathak JK (2010) Rapid assessment of water quality index of Ramganga river, Western Uttar Pradesh (India) using a computer programme. Nat Sci 8(11):1-8.

APHA. (2017) Standard methods for the examination of water and waste water, $21^{\text {nd }}$ ed. American Public Health Association, Washington, D.C..

Balan IN, Shivakumar M, Kumar PDM (2012) An assessment of ground water quality using water quality index in Chennai, Tamil Nadu, India. Chron Young Sci 3(2):146150 .

Bera,RatiKanta and Rifat Akbar (2012).Determination of Physico Chemical Parameters of Brahmani River Water at Kansar, Jalda Area, Rourkela. J. Chem. Bio. Phy. Sci. Sec. 2(4) 2188-2192.

Bhutiani Rakesh and Ahamad Faheem 2018. Efficiency assessment of Sand Intermittent Filtration Technology for waste water Treatment. International Journal of advance research in science and engineering (IJARSE), 7(03): 503-512.

Bhutiani, R., Khanna,D.R., Ram Khushi, Ahamad Faheem and Tyagi Varun, 2016. Quality assessment of Ganga river at Haridwar with Reference to various physico-chemical parameters. Biotechnology International, 9(1):17-24
Bhutiani, R., Khanna,D.R., Ahamad Faheem and Tyagi Varun, 2018. Assessment of water quality status of Malin River at Najibabad, Bijnor (UP), Water Biology:281-307.

Bhutiani, R., Khanna,D.R., Ahamad Faheem and Tyagi Varun, 2018. Physico-chemical characterization of river Ganga at Haridwar, Uttarakhand, Water Biology:143-159.

Bhutiani R., Ruhela Mukesh, Ahamad Faheem, 2017. Limnological Characterisation of Hindon River at NCR (Uttar Pradesh) India. Environ. Cons. Jour. 18(1\&2):219229.

Bhutiani R., Ahamad Faheem, Tyagi Varun and Ram Khushi, 2018. Evaluation of water quality of River Malin using water quality index (WQI) at Najibabad, Bijnor (UP) India, Environment Conservation Journal 19 (1\&2):191-201.

Chauhan A, Singh S.,2010. Evaluation of Ganga water for drinking purpose by water quality index at Rishikesh, Uttarakhand, India. Rep Opin 2(9):53-61.

Chowdhury RM, Muntasir SY, Hossain MM (2012) Water quality index of water bodies along Faridpur-Barisal road in Bangladesh. Glob Eng Tech Rev 2(3):1-8.

Brown, R.M., McClelland N.I., Deininger R.A., Tozer R.G. (1970). A water quality index-Do we dare? Water and Sewage Works, 117(10):339-343.

Brown, R.M., McClelland, N.I., Deininger, R.A., Landwehr, J.M., 1973. Validating the WQI. The paper presented at national meeting of American Society of Civil Engineers on water resources engineering, Washington, DC.

Cude, C.G., 2001. "Oregon water quality index: a tool for evaluating water quality management effectiveness", J. American Water Resou. Assoc., 37(1):125-137.

Kamal D., Khan A.N, , Rahman M.A, Ahamad F., 2007. Study on the physico chemical properties of water of Mouri River Khulna, Bangladesh. Pakistan Journal of Biological Sciences 10(5): 710-717.

Khanna D.R and Bhutiani R., 2008. Laboratory manual of water and Wastewater Analysis.Daya Publishing House, New Delhi. 1-184.

Isaq Fouzia and Khan Amir .2012. Comparative assessment of physico chemical conditions and Plankton diversity of River Tons and Asan in Dehradun, Uttrakhand. Adv. Appl. Science Res. 4(2): 342-355.

Gupta Nutan, Ramesh C. Sharma and Tripathi A.K., 2008. Study of Bio-Physical-Chemical parameters of Mothronwala swamp, Dehradun. Journal of Environmental Biology, 29 (3): 381-386.

Imnatoshi and Sharif U.Ahmed 2012. Geomorphology and Seasonal variations of Physico-Chemical Parameters of Doyang river Nagaland. The Ecoscan, 6(1\&2):5-9. 
Khan M.Y., Mir Shabber, Imtiyaz A. Raja and Nazir.A.Wani, 2012. Physico chemical analysis of River Jhelum (Kashmir).Global Journal of Science Frontier Research Interdisciplinary , 12:325-330.

Khanna D.R, Bhutiani R, Ruhela Mukesh (2012).Fish diversity and their Limnological status of Ganga River System in Foothills of Garhwal Himalya, Uttrakhand, India. Journal of Environmental Research and Development, 7(4): 13741380.

Khanna D.R., Bhutiani R., Matta Gagan, Singh Vikas and Ishaq Fouzia 2012. Seasonal variation in physico-chemical characteristic status of River Yamunain Doon Valley of Uttarakhand. Environ. Cons. Jour., 13(1\&2):119-124.

Khanna D.R., Bhutiani Rakesh, Tyagi Varun and Ahamad Faheem, 2014. Impact of Sugar mill Effluent on Physicochemical properties of Malin River in Najibabad. Indian $\boldsymbol{J}$. Sci. Res. Spl. Ed. NSESIR :5-10

Khanna, D.R and Bhutiani, R., 2003. Limnological characteristics of the River Ganga at Haridwar (Uttaranchal),U.P. J. Zool., 23(3):179-183.

Lumb A, Halliwell D, Sharma T., 2006. Application of CCME water quality index to monitor water quality: a case of the Mackenzie River basin, Canada. Environ Monit Assess 113:411-429.

Malik D.S, Umesh Bharti, Pawan Kumar, 2010. Macro benthic diversity in relation to biotic indices in Song River at Dehradun, India. Environment Conservation Journal 11 (1 \& 2): 99-104.

Karla Neeraj, Kumar Rajesh, Yadav S.S and Singh R. T., 2012. Physico chemical analysis of ground water taken from five blocks (Udwantnagar, Tarari, Charpokhar, Piro, Sahar)of southern Bhojpur Bihar. Journal of Chemical and Pharmaceutical Research, 4(3):1827-1832.

Ruhela Mukesh, Bhutiani Rakesh, Ahamad Faheem,2017. Pollution Status of River Hindon from Ghaziabad to Noida with Special Reference to Heavy Metals. International Journal of Advance Engineering and Research Development , 4( 8):540-548.

Sahu B.K, Rao R.J and Behra 2005. Physico chemical characteristics of the Ganga River water (RishikeshKanpur) within twenty four hours. Eco.Env and Cons. 1(14):35-38.

Sayeswara H.A, Mahesh Anand Gowdar, and Manjunatha, R., 2011. A preliminary study on Ecological characteristics of Sominkoppa pond, Shivamagga, Karnatka. International Quarterly Journal of Environmental Sciences. The Eco scan , 5(1\&2): 121-129.

Tyagi S, Sharma B, Singh P, Dobhal R., 2013. Water quality assessment in terms of water quality index. Am $\boldsymbol{J}$ Water Resour, 1(3):34-38.

US EPA, 2009. Environmental impact and benefits assessment for final effluent guidelines and standards for the construction and development category. Office of Water, Washington, DC. EPA821-R-09-012

Venkatesharaju, K., Ravikumar, P., Somashekhar, R.K., Prakash, K.L., 2010. Physico-chemical and bacteriological investigation on the river Cauvery of Kollegal stretch in Karnataka. Kathmandu University. J Sci Eng Tech 6(1):10-15

World health report 2004. changing history. Geneva, World Health Organiza- tion, 2004

Yadav R.C. and Srivastava V.C., 2011. Physico chemical properties of the water of River Ganga at Ghazipur. Indian J. Science Res., 2 (4):41-44. 